\title{
Effect of seaweed extract of Sargassum vulgare on germination behavior of two bean cultivars (Phaseolus vulgaris $\mathrm{L}$ ) under salt stress
}

\author{
Latique Salma ${ }^{1}$, Elouaer Mohamed Aymen ${ }^{2}$, Souguir Maher ${ }^{2}$, Aloui Hassen ${ }^{2}$, \\ Hannachi Chérif ${ }^{2}$, Chernane Halima $^{1}$, Mansori Mounir ${ }^{1}$, Elkaoua Mimoun ${ }^{1}$. \\ ${ }^{I}$ Faculty of Sciences and Technology, Cadi Ayyad University of Marrakech, Morocco, Department of Biology, \\ Laboratory of Biotechnology, Valorization and Protection of Agro-Resources. \\ ${ }^{2}$ High Institute of Agriculture, Chott-Mariem, University of Sousse, Tunisia, Department of Horticulture and \\ Landscape RU: "Conservation and Valorization of vegetal Resources by creation of botanical garden".
}

\begin{abstract}
Salt stress is a major adverse factor that can lower seed germination and seedlings growth, leading to reduced plant growth and ultimately lower crop productivity in arid and semi arid regions of the world. Bean (Phaseolus vulgaris L.) is an important crop occupying a large area in both Morocco and Tunisia, where salt stress is the most limiting factor. In the present investigation, an attempt has been made to study the effect of seaweed liquid extract (SWE) from Sargassum vulgare at different concentrations on seed germination and seedling growth of two bean cultivars (Phaseolus vulgaris L) under salt stress.
\end{abstract}

Keywords: Seaweed extract, bean, seed germination, seedling growth, salt stress

\section{Introduction}

Abiotic stresses are major constraints on worldwide crop production, and salinity is one of the biggest problems affecting about one-third of the irrigated land on earth [1]. Salinity may affect seed germination either by creating an osmotic stress thus preventing the seed from water uptake or through the toxic effects of sodium and chlorides ions on the germinating seed [2]. Seeds and seedlings are particularly vulnerable to increasing salinity because at that stage plants have not yet developed the physiological mechanisms to tolerate rising salinity concentrations [3]. This has led to concentrate research efforts on salt tolerance of plants, in order to improve crop yield [4]. Many research studies have shown the beneficial effect of seaweeds extracts in stimulating growth of plants [5] [6]. They contain all major and minor plant nutrients including bio-control properties; they also contain organic compounds such as auxins, gibberellins and precursors of ethylene and betaine that impact plant growth [7]. Beneficial effects from the use of seaweed extracts as natural regulators have induced increased crop yield and plant vigor to withstand adverse environmental effects [8]. Bean (Phaseolus vulgaris $\mathrm{L}$ ) is a major food legume and an important source of protein in many countries. However, this crop is sensitive to salinity, like many other leguminous crops [9]. That's why; this study was undertaken to test the effect of seaweed liquid fertilizer extract of Sargassum vulgare on germination behavior of two bean (Phaseolus vulgaris $\mathrm{L}$ ) cultivars under salt stress.

\subsection{Experimental material}

\section{Materials And Methods}

Seeds of two bean (Phaseolus vulgaris L.) cultivars were included in this study. The first one is a Moroccan cultivar, Paulista, which is the most cultivated by Moroccan farmers and the second cultivar is a Tunisian one, Soisson Nain hâtif (SNH).

\subsection{Seed material}

Germination experiment was conducted in the laboratory of High Institute of Agriculture Chott Mariem, Tunisia to analyze the effect of sodium chloride salinity added with seaweed liquid extract or not on germination behavior and seedling growth of bean. Seeds used in this study were Phaseolus vulgaris $\mathrm{L}$. This plant belongs to the family of Fabaceae. It is moderately sensitive to salt stress.

\subsection{Collection of seaweeds}

Seaweeds Sargassum vulgare (Phaeophyceae) used in the present study were collected from the coastal area of Chott Mariem, Tunisia $\left(35.8^{\circ} \mathrm{N}\right.$ and $\left.10.6^{\circ} \mathrm{E}\right)$. Morphologically distinct thallus of algae were placed in polythene bags and transported to the laboratory. Samples were washed thoroughly using tap water to remove the salt. 


\subsection{Seaweeds treatment}

Seaweeds were shade dried for four days, followed by oven dry for $12 \mathrm{~h}$ at $60^{\circ} \mathrm{C}$. Then the materials were hand crushed and made as coarse powder, was added with distilled in a ratio of 1:20 (w/v) and boiled at $121^{\circ} \mathrm{C}$ for 30 minutes. The hot extracts were filtered through a double-layered cheese cloth and allowed to cool at room temperature [10]. The resulting supernatant was taken as $100 \%$ seaweed liquid extracts. Seaweed liquid extracts were prepared with different doses: control $(0 \%), 0.2 \%$ and $0.5 \%$.

\subsection{Seed Treatment}

Ten Seeds of bean were placed in $9 \mathrm{~cm}$ Petri dishes on a two layers of filter paper (Whatman \# 41). Salt stress was induced by sodium chloride $(\mathrm{NaCl})$. Three sets were treated with 0,2 and $4 \mathrm{~g} / \mathrm{l}$ of $\mathrm{NaCl}$ and were considered as control as they don't receive extract of Sargassum vulgare. Seeds under study were treated with salt at various concentrations $(0,2$ and $4 \mathrm{~g} / \mathrm{l}$ of $\mathrm{NaCl})$ and each concentration was supplemented with seaweed extracts (SWE) of Sargassum vulgare separately at two different doses (S1: 0.2\% and S2: 0.5\%). All sets were labeled as control (non-treated seeds with seaweeds extract of Sargassum vulgare); S1 (Seeds supplemented with $0.2 \%$ of Sargassum vulgare extract); S2 (seeds supplemented with $0.5 \%$ of Sargassum vulgare extract).

Seeds were placed on top of the filter paper wetted with $5 \mathrm{ml}$ of each different concentrations of seaweed extracts in the Petri dishes and were kept under photoperiod for 14 days. The culture room temperature was maintained at $25^{\circ} \mathrm{C}$. Seed germination was recorded daily up to day 14 after the start of the experiment.

After fourteen days, seedlings were taken for the observations. Parameters measured in this experiment were:

Total seed germination rate $(\mathrm{TG})$ measured in the sixth day using the formula TG $(\%)=($ total number of germinated seeds/ total seed) x 100 .

Mean germination time (MGT) calculated according the formula of Ellis and Roberts [11]. MGT $=\Sigma$ (ni/di). With ni: number of germinated seeds and di: day of counting.

Seedling fresh, dry weight and radicle length were measured. Seedlings kept at $60 \pm 5^{\circ} \mathrm{C}$ for 48 hours and weighted for determination of their dry weights.

\subsection{Statistical Analysis}

Data were analyzed statistically for standard deviation using SPSS 13.0. All measurements were performed with triplicates and the mean values were presented.

\subsection{Total Germination}

\section{Results And Discussion}

The percentage of germination was reduced in both bean seeds (Phaseolus vulgaris L) genotypes as response to salinity stress. The decrease in the germination percentage was found to be more with the increasing concentration of $\mathrm{NaCl}$. When the treated seeds were supplemented with SWE $(0.2$ and $0.5 \%)$ along $\mathrm{NaCl}$ salt, the germination percentage was increased (Fig. 1 and 2). Total germination from both treated and non-treated seeds with SWE of Sargassum vulgare decreased significantly with increasing $\mathrm{NaCl}$ salinity. However, this reduction in total germination was significantly higher for non-treated seeds, compared to treated ones. Data suggested a reduction of about $10 \%$ on total germination due to an increase in salinity from 0 to $4 \mathrm{~g} / \mathrm{l}$. Results indicated that application of seaweeds extract increase germination by $2 \%$ and $5 \%$ in both bean cultivars using respectively SWE S1 (0.2\%) and S2 (0.5\%) when compared to control seeds (Figs. 1 and 2).

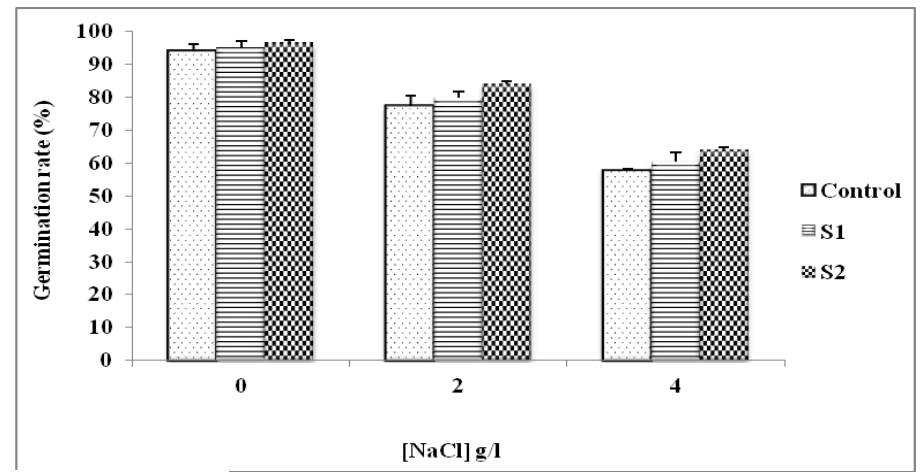

Figure 1.Effect of Sargassum vulgare extract on germination rate of Moroccan bean cv.Paulista under different concentration of $\mathrm{NaCl}$. 


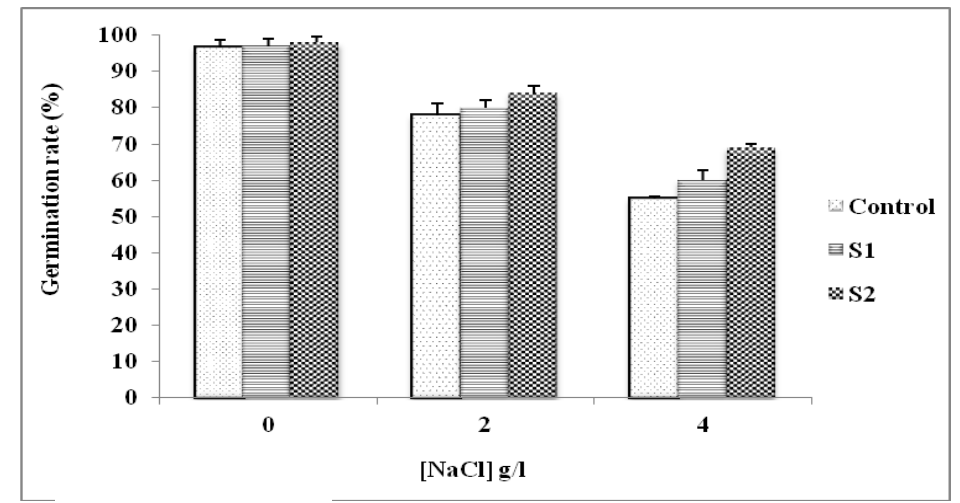

Figure 2. Effect of Sargassum vulgare extract on germination rate of Tunisian bean under salt stress.

In general, increasing salinity causes a decrease in bean germination; this may be due to the toxic effects of $\mathrm{Na}^{+}$and $\mathrm{Cl}^{-}$in the process of germination [12]. It seems also that salinity stress affects seed germination via the limitation of seed water absorption [13], excessive use of nutrient pool [14] and creation of disorders in protein synthesis.

The effects of seaweed extracts on germination of various crops have been shown by many authors [15], [16]. It was indicated that seaweeds extracts induce leakage of inhibitors possibly absisic acid from the seeds which improve germination percentage [17]. The involvement of growth regulating substances in seaweed extracts like ethylene, kinetin and gibberellic acid were effective on reversal of induced dormancy in seeds [18].

The ameliorating effect of SWE may be due to the growth hormones available which would have triggered de novo the synthesis of hydrolytic enzymes. This present study is in accordance with the earlier results of [19], [20] and [21]. It may be due to the presence of growth-promoting substance in SWE [22].

\subsection{Mean germination time (MGT)}

Results showed that salinity significantly increase mean germination time (MGT) for both treated and non-treated bean seeds with seaweed extract. However, treated seeds with Sargassum vulagre extract have lower MGT compared to control seeds. Data in Table 1 indicated that increasing salinity significantly delayed mean germination time of 1.218 days. However, application of SWE significantly shortened MGT when compared to control seeds (Table 1). Data in Table 2 show also that rising concentration of $\mathrm{NaCl}$ delayed significantly MGT in Moroccan bean genotypes; this delay was less pronounced in treated seeds with SWE. According to [23], most plants are more sensitive to salinity during germination and seedling growth. This is in agreement with our study whereby a lower mean germination time was found with treatments of Sargassum vulgare.

The probable reason for early emergence of the seaweed extract treated seeds maybe due to the completion of pre-germination metabolic activities making the seed ready for radicle protrusion and the SWE treated seeds germinated soon after planting compared with untreated ones [24].

Furthermore, seaweed extracts contain various betaines and betaine-like compounds [25], [26]. In plants, betaines serve as a compatible solute that alleviates osmotic stress induced by salinity stress. Those compatibles solutes have been shown to play a part in successful formation of somatic embryos from cotyledonary tissues and mature seeds of tea [27]. All that information supports our results about seed germination and improved mean germination time with SWE.

\subsection{Seedling fresh and dry weight}

Increasing salinity decreased bean seedlings fresh and dry weight for both treated and un-treated seeds. In fact, the increase in salt concentration in culture medium brought down seedlings fresh weight from $1.986 \mathrm{~g}$ at $0 \mathrm{~g} / \mathrm{l}$ to reach $1.593 \mathrm{~g}$ at $4 \mathrm{~g} / \mathrm{l}$ (Table 1). However, seeds supplemented with SWE showed better performance than non-supplemented seeds. Data in Table 1 shows that seeds supplemented with $0.2 \%$ and $0.5 \%$ of SWE enhanced beans seedling fresh (SFW) and dry weight (SDW) as compared to control.

Reduction in seedlings growth (seedlings fresh and dry weights) was visible in salt stressed seeds with increasing concentration of $\mathrm{NaCl}$. However, the application of SWE improved seedlings growth which was visible in seeds supplemented with SWE of Sargassum vulgare.

Reduction in seedling growth as a result of salt stress has been reported in several others species [28], [29]. Salinity has both osmotic and specific ionic effects on seedlings growth [30]. Similarly, toxic ion accumulation ( $\mathrm{Na}+$ and $\mathrm{Cl}-$ ) negatively affect plant metabolism [31]. It has also been reported that salinity suppresses the uptake of essential nutrients like P and K [32], which could adversely affect seedlings growth. [33] have reported that salinity reduced fresh and dry weight of maize seedlings. 
Seaweed include macro and microelement nutrients, amino acids, vitamins, cytokinins, auxins, and abscisic acid that affect cellular metabolism in treated seeds, leading to enhanced seedlings growth [34], [35]. In addition, seaweeds contain precursors of elicitor compounds that promote germination [36].

Another possibility is the presence of polysaccharides in SWE, as sugars that are known to improve seedling growth in a similar way to hormones [37]. Zeatin is another candidate for induction of rooting in plants by seaweed [38].

Furthermore, seaweed extracts contain various betaines and betaine-like compounds [39], [40]. In plants, betaines serve as a compatible solute that alleviates osmotic stress induced by salinity stress.

\subsection{Radicle length}

Salinity had an inhibitory effect on radicle length for both treated and un-treated seeds (Table 1 and 2). However, this effect was significantly less pronounced in seedlings from treated seed with Saragasum vulgare extract in comparison with control seeds of Moroccan cultivar and Tunisian one. The application of SWE improved the growth of the radicle significantly. The increased in radicle length may be due to presence of some growth promoting substances such as IAA and IBA, Gibberellins, Cytokinins, micronutrients and amino acids [41].

Tableau 1. Effect of Sargassum vulgare extract on seedling growth of Tunisian bean cultivar under salt stress.

\begin{tabular}{|c|c|c|c|c|c|c|c|c|c|}
\hline & \multicolumn{3}{|c|}{$0 \mathrm{~g} / 1$} & \multicolumn{3}{|c|}{$2 \mathrm{~g} / 1$} & \multicolumn{3}{|c|}{$4 \mathrm{~g} / 1$} \\
\hline & Control & S1 & S2 & Control & S1 & S2 & Control & S1 & S2 \\
\hline MGT & $\begin{array}{c}2.521 \pm \\
0.154 \\
\end{array}$ & $\begin{array}{c}2.127 \pm \\
0.103 \\
\end{array}$ & $\begin{array}{c}1.987 \pm \\
0.238 \\
\end{array}$ & $\begin{array}{c}2.839 \pm \\
0.731 \\
\end{array}$ & $\begin{array}{c}2.625 \pm \\
0.278 \\
\end{array}$ & $\begin{array}{c}2.387 \pm \\
0.309 \\
\end{array}$ & $\begin{array}{c}3.739 \pm \\
0.481 \\
\end{array}$ & $\begin{array}{c}3.426 \pm \\
0.521 \\
\end{array}$ & $\begin{array}{c}3.135 \pm \\
0.635 \\
\end{array}$ \\
\hline SFW (mg) & $\begin{array}{l}2055.66 \\
\pm 0.178 \\
\end{array}$ & $\begin{array}{l}2548.06 \\
\pm 0.522 \\
\end{array}$ & $\begin{array}{c}2763.58 \pm \\
0.701 \\
\end{array}$ & $\begin{array}{c}1926.81 \pm \\
0.403\end{array}$ & $\begin{array}{l}2183.72 \\
\pm 0.181 \\
\end{array}$ & $\begin{array}{c}2311.34 \pm \\
0.272\end{array}$ & $\begin{array}{c}1827.98 \pm \\
0.837\end{array}$ & $\begin{array}{c}1932.92 \pm \\
0.490\end{array}$ & $\begin{array}{c}2064.73 \pm \\
0.406\end{array}$ \\
\hline SDW (mg) & $\begin{array}{c}518.56 \pm \\
1.078 \\
\end{array}$ & $\begin{array}{c}576.46 \pm \\
0.622 \\
\end{array}$ & $\begin{array}{c}626.32 \pm \\
0.701\end{array}$ & $\begin{array}{c}514.26 \pm \\
0.403 \\
\end{array}$ & $\begin{array}{r}536.43 \\
\pm 0.181 \\
\end{array}$ & $\begin{array}{c}562.73 \pm \\
0.272 \\
\end{array}$ & $\begin{array}{c}459.64 \pm \\
0.837 \\
\end{array}$ & $\begin{array}{c}496.63 \pm \\
0.490\end{array}$ & $\begin{array}{c}517.76 \pm \\
0.406 \\
\end{array}$ \\
\hline $\mathrm{RL}(\mathrm{mm})$ & $\begin{array}{c}10.67 \pm \\
1.178\end{array}$ & $\begin{array}{c}27.45 \pm \\
0.422\end{array}$ & $\begin{array}{c}33.65 \pm \\
0.701\end{array}$ & $\begin{array}{l}7.29 \pm \\
0.403\end{array}$ & $\begin{array}{c}12.74 \pm \\
0.181\end{array}$ & $\begin{array}{c}26.39 \pm \\
0.272\end{array}$ & $\begin{array}{l}4.86 \pm \\
0.837\end{array}$ & $\begin{array}{c}7.68 \pm \\
0.490\end{array}$ & $\begin{array}{l}9.16 \pm \\
0.406\end{array}$ \\
\hline
\end{tabular}

Tableau 2. Effect of Sargassum vulgare extract on seedling growth of Moroccan bean cultivar under salt stress.

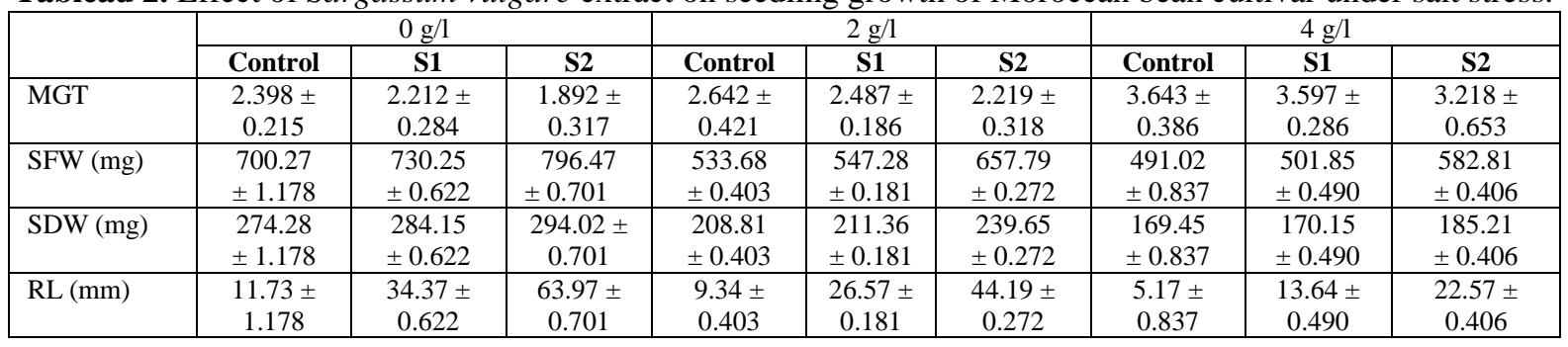

\section{Conclusion}

It is clear from the current study that seaweeds extract of Sargassum vulgare have an ameliorating effect on bean seeds under salt stress because of the presence of growth hormones, nutrients and other important physiochemical compounds. So the supplementation of SWE could be used as a biological amendment in soil reclamation technique which can boost food production not only in cultivated lands but also in barren soils accumulated with salt. Further study will be needed to test the influence of SWE on later growth and yield of bean cultivated in salt stress.

[1] K. Mengel, E.A. Kirkby, H. Kosegarten and T. Appel, Principles of plant nutrition. Kluwer Academic Publishers, Dordrecht, The Netherlands. 2001.

[2] M.K. Hosseini, A.A. Powell and I.J. Bingham. The interaction between salinity stress and seed vigor during germination of soyabeen seeds. Seed Sci. Technol. 31, 2003, 715-725.

[3] P. Adam, Salt marsh ecology. Cambridge University Press, Cambridge, UK, 1990.

[4] J.K. Zhu, Plant salt tolerance. Trends Plant Sci. 6, 2001, 66-71.

[5] G. Blunden, Agricultural uses of seaweeds and seaweed extracts. In: Seaweed resources in Europe: uses and potential (Guiry MD, Blunden G, eds.). John Wiley \& Sons, Chichester, 1991, 65-81.

[6] W.S. Washington, S. Engleitner, G. Boontjes, N. Shanmuganathan, Effect of fungicides, seaweed extracts, tea tree oil and fungal agents of fruit rot and yield in strawberry. Aust J Exp. Agric , 39, 1999, 487-494.

[7] Y. Wu, T. Jenkins, G. Blunden, C. Whapham, S.D. Hankins, The role of betains in alkaline extracts of Ascophyllum nodosumin reduction of Meloidogyne javanica and M. incognita infestations of tomato plants. Fund Appl Nematol 20, 1997, 99-102.

[8] B.C. Featonby-Smith, J. Van Staden, The effect of seaweed concentrate and fertilizer on the growth of Beta vulgaris. Z Pflanz Bodenkunde 112, 1983, 155-162.

[9] M. Ashraf, and A.Waheed, Responses of some genetically diverselines of chickpea (Cicer arietinum L.) to salt. Plant Soil.154, 1993, 257-266. 
[10] K. Rama Rao, Preparation of liquid seaweed fertilizer from Sargassum, Seaweed Research and Utilization Association Workshop on algal products and Seminar on Phaeophyceae in India, Madras, India. 6, 1990, 4 - 7.

[11] RA. Ellis, EH. Roberts, The quantification of ageing and survival in orthodox seeds. Seed Science Technology 9, 1981, 373-409.

[12] M. Khajeh-Hosseini, AA. Powell, IJ. Bimgham, The interaction between salinity stress and seed vigor during germination of soybean seeds. Seed Science Technology 31, 2003, 715-725.

[13] GL. Dodd, LA. Donovan, Water potential and ionic effects on germination and seedling growth of two cold desert shrubs. American Journal of Botany 86, 1999, 1146-1153.

[14] A. Bouaziz, DR. Hicks, Consumption of wheat seed reserves during germination and early growth as affected by soil water potential. Plant and Soil 128, 1990, 161-165.

[15] J.S. Taylor, K.N. Harker, J.M. Robertson, K.R. Foster. The effect of a seaweed extract containing cytokinin on the growth and yield of barley. Can. J. Plant Sci., 70, 1990, 1163-1167.

[16] M. Moller, M.L. Smith, The applicability of seaweed suspensions as priming treatments of lettuce (Lactuca sativa L.) seeds. Seed Sci. Technol., 26: 1998, 4256438 .

[17] H.L. Speer and D. Tupper, The effects of lettuce seed extracts on lettuce seed germination. Can. J. Bot., 53, 1975, 593-599.

[18] J.R. Dunlap and P.W. Morgan, Reversal of induced dormancy in lettuce by ethylene, kinetin and gibberellic acid. Plant Physiol. 60 , 1977, 222-224.

[19] K. Venkataraman, V.R. Mohan, R. Murugeswari, Seaweed Research and Utilization. 16(1-2), 1993, 23-27.

[20] VR. Mohan, V. Venkataraman Kumar, R. Murugeswari, S. Muthuswami, Effect of crude and commercial seaweedextracts on seed germination and seedling growth in Cajanus cajan L. Phykos 33: 1994, 47-51.

[21] G. Johnsi Christobel, Effect of seaweed extract (Sargassum wightii L.) on the germination and growth of green gram (Phaseolus aureus L.). Journal of Basic Applied Biology. 2. 2008, 105-108.

[22] D.L. Jennings and B.M.M. Tulloch, Studies on Factors which promote Germination of Raspberry Seeds. Journal of Experimental Botany. 16 (2), 1965, 329-340.

[23] D.H. Reinhardt, T.L. Rost, Primary and lateral root development of dark- and light-grown cotton seedlings under salinity stress. Bot Acta 108, 1995, 403-465.

[24] N. Ozbingol, F. Cornineau, SPC. Groot, RJ. Bino, D. Come, Activation of the cell cycle in tomato (Lycopersicon esculentum Mill.) seeds during osmoconditioning as related to temperature and oxygen. Annals of Bot., 84, 1999, 245-251.

[25] G. Blunden, AL. Cripps, SM. Gordon, TG. Mason, CH. Turner, The characterization and quantitative estimation of betaines in commercial seaweed extracts. Bot Mar 29, 1986, 155-160.

[26] M. Ghoul, J. Minet, T. Bernard, E. Dupray, M. Cornier, Marine macroalgae as a source for osmo-protection for Escherichia coli. Microb Ecol 30, 1995, 171-181.

[27] A. Akula, C. Akula, M. Bateson, Betaine a novel candidate for rapid induction of somatic embryogenesis in tea (Camellia sinensis (L.) O. Kuntze). Plant Growth Regulation 30, 2000, 241-246.

[28] AK. Achakzai, SA. Kayani, Z. Hanif, Effect of salinity on uptake of micronutrients in sunflower at early growth stage. Pakistan Journal of Botany 42, 2010, 129-139.

[29] M. Akram, MY. Ashraf, R. Ahmad, EA. Waraich, J. Iqbal, M. Mohsan, Screening for salt tolerance in maize (Zea maysL.) hybrids at an early stage. Pakistan Journal of Botany 42, 2010, 141-151.

[30] ML. Dioniso-Sese, S. Tobita, Effects of salinity on sodium content and photosynthetic responses of rice seedlings differing in salt tolerance. Journal of Plant Physiology 157, 2000, 54-58.

[31] C. Grieve, MH. Fujiyama. The response of two rice cultivars to external $\mathrm{Na}^{+} / \mathrm{Ca}^{+}$ratio. Plant Soil 103, 1987, 345-250.

[32] M. Nasim, R. Qureshi, T. Aziz, M. Saqib, S.Nawaz, ST Sahi, S. Pervaiz, Growth and ionic composition of salt stressed Eucalyptus camaldulensis and Eucalyptus teretcornis. Pakistan Journal of Botany 40, 2008, 799-805.

[33] N. Cicek, H. Cakirlar, The effect of salinity on some physiological parameters in two maize cultivars. Bulgarian Journal of Plant Physiology 28, 2002, 66-74.

[34] IJ. Crouch, J. van Staden, Evidence for the presence of plant growth regulators in commercial seaweed products. Plant Growth Regul 13, 1993, 21-29.

[35] WA. Stirk, GD. Arthur, AF. Lourens, O. Novák, M. Strnad, J. van Staden. Changes in cytokinin and auxin concentrations in seaweed concentrates when stored at an elevated temperature. J Appl.Phycol. 16, 2004, 31-39.

[36] WA. Stephenson Seaweed in agriculture and horticulture, $3^{\text {rd }}$ edn. Barglya \& Gylver Rateaver, 1974, San Diego.

[37] F. Rolland, B. Moore, J. Sheen, Sugar sensing and signaling in plants. The Plant Cell 14, 2002, 185-205.

[38] JF. Finnie, J. van Staden, Effect of seaweed concentrates and applied hormones on in vitro cultured tomato roots. J Plant Physiol. $120,1985,215-222$.

[39] G. Blunden, S.M. Gorden, Betaines and their sulphonio analogues in marine algae. In: F.E. Round and D.J. Chapman, (eds.) Progress in Phycological Research, 4, Biopress, Bristol. 1986. 39-80.

[40] M. Ghoul, J. Minet, T. Bernard, E. Dupray, M. Cormier. Marine Macroalgae as a Source for Osmoprotection for Escherichia coli. Microbial Ecology 30, 1995, 171-181.

[41] S.B. Challen, and J.C. Hemingway, Growth of higher plants in response to feeding with seaweed extracts. Proc. Fifth Int.Seaw.Symp. 1966, 359 - 367. 